Article

\title{
The Myth of Apolitical Volunteering for Refugees: German Welcome Culture and a New Dispositif of Helping
}

\author{
Larissa Fleischmann ${ }^{1, *}$ and Elias Steinhilper ${ }^{2}$ \\ ${ }^{1}$ Department for Social and Cultural Anthropology, University of Konstanz, 78467 Konstanz, Germany; \\ E-Mail: larissa.fleischmann@uni-konstanz.de \\ 2 Institute of Humanities and Social Sciences, Scuola Normale Superiore, 50123 Florence, Italy; \\ E-Mail: elias.steinhilper@sns.it \\ * Corresponding author
}

Submitted: 23 March 2017 | Accepted: 12 July 2017 | Published: 19 September 2017

\begin{abstract}
During the so-called "refugee crisis", the notion of an unparalleled German hospitality toward asylum seekers circulated within the (inter)national public sphere, often encapsulated by the blurry buzzword "Welcome Culture". In this article, we scrutinize these developments and suggest that the image of the so-called "crisis" has activated an unprecedented number of German citizens to engage in practices of "apolitical" helping. We argue that this trend has contributed to the emergence of what we term a new dispositif of helping, which embeds refugee solidarity in humanitarian parameters and often avoids an explicit political, spatial, and historical contextualization. This shift has activated individuals from the socio-political centre of society, well beyond the previously committed radical-left, antiracist, and faith-based groups. However, we aim to unmask forms of "apolitical" volunteering for refugees as a powerful myth: the new dispositif of helping comes with ambivalent and contradictory effects that range from forms of antipolitics to transformative political possibilities within the European border regime.
\end{abstract}

\section{Keywords}

civil society; Germany; humanitarianism; migration regime; refugee crisis; solidarity; volunteering

\section{Issue}

This article is part of the issue "Perspectives on the European Border Regime: Mobilization, Contestation, and the Role of Civil Society", edited by Ove Sutter and Eva Youkhana (University of Bonn, Germany).

(C) 2017 by the authors; licensee Cogitatio (Lisbon, Portugal). This article is licensed under a Creative Commons Attribution 4.0 International License (CC BY).

\section{Introduction: The Ambivalence of Volunteering in Times of a "Refugee Crisis"}

During the so-called "refugee crisis", ${ }^{1}$ the notion of an unparalleled German hospitality toward asylum seekers circulated within the (inter)national public sphere (Akrap, 2016; The Economist, 2015). Indeed, along with the rising numbers of asylum seekers, a "new movement of volunteering for refugees" seems to have emerged throughout the country (Karakayali \& Kleist, 2015, 2016). More citizens than ever before provided support for refugees in different kinds of ways, ranging from highly visible ad-hoc actions, such as reception committees at railway stations or the overwhelming readiness to donate (Paterson, 2015), to more sustained engagements for asylum seekers, including the organization of language courses and leisure time activities, mentoring, and legal support (Aumüller, Daphi, \& Biesenkamp, 2015; Daphi, 2016). These newly engaged volunteers, who often had not been committed to refugees before the recent developments, formed grass-roots groups and citizens' initiatives all over the country, involving individuals from a

\footnotetext{
${ }^{1}$ We intentionally put the term "refugee crisis" in inverted commas because we refer to the dominant framing of the developments in summer 2015. However, we claim that the phenomenon is better depicted as a "crisis of the European border regime" (Schwiertz \& Ratfisch, 2016), a "crisis of refugee protection" (Scherr, 2016), a "political crisis" (Geddes, 2017) or, better, by avoiding the crisis terminology altogether, as "the long summer of migration" (Kasparek \& Speer, 2015). In section two, we will outline how such metaphors of a "crisis" come with problematic effects.
} 
broad spectrum well beyond the previously committed radical-left, antiracist, and faith-based groups. The blurry buzzword "Welcome Culture" came to encapsulate this new mainstreaming of supportive attitudes towards asylum seekers within German society (Hamann \& Karakayali, 2017; Jungk, 2016). ${ }^{2}$ Angela Merkel's famous quote "Wir schaffen das!" ["We can do this!"] helped to raise the willingness for public support and became an often cited mantra for new volunteers (Glorius, 2017).

In this article, we aim to scrutinize this upsurge of citizens' commitment to refugees. We claim that the image of the so-called "crisis" mobilized previously nonengaged parts of society to provide temporary "help" during the perceived emergency situation. This increase in committed citizens came with a myth of "apolitical" 3 volunteering for refugees and its framing within humanitarian parameters. Many volunteers explicitly distance themselves from "being political" and claim that they "just want to help" in order to relieve suffering (Karakayali \& Kleist, 2016; Kreck \& Gerbing, 2015).

We put forward a conceptual reading of these developments as implicating the formation of a new dispositif $^{4}$ of helping. Rather than being located outside politics, we will demonstrate that the new forms of volunteering are indeed highly political, although they come with ambivalent effects. On the one hand, they illustrate what has been discussed as the "limits" of humanitarianism (see e.g., Fassin, 2012) or the "antipolitics of care" (Ticktin, 2011): instead of initiating transformations, they can reinforce and become complicit in an increasingly repressive migration regime by reproducing hegemonic inequalities and hierarchies. On the other hand, these developments pull refugee solidarity out of a niche and can come with political possibilities that foster change. In resonance with the writings of Jacques Rancière (1999, 2010), we understand the political as a "rupture" in the dominant order-i.e. the migration regime-that comes with transformative effects which alter the status quo towards a more egalitarian alternative.

This article builds, in large parts, on a meta-analysis of existing qualitative and quantitative studies on the trend of volunteering for refugees in Germany. We therefore outline the key findings of seminal contributions that have emerged on the issue, mostly in German. In combining and discussing these predominantly descriptive studies, we intend to fulfil two tasks: firstly, we provide a more theoretically informed and systematic account of the developments in Germany; and sec- ondly, we extend the debate to the Anglophone audience, which has so far scarcely addressed the peculiar, ambivalent case of the German Welcome Culture. This might also enable future studies to compare and parallel this case with developments in different national contexts. Beyond a secondary analysis, this article is also informed by our own empirical research on refugee solidarity and refugee self-organization-at times more, at times less, explicitly. ${ }^{5}$

To unfold our argument on the German Welcome Culture, we first sketch out the theoretical underpinnings of the new dispositif of helping (Section 2). We then discuss how this dispositif might function as a form of "antipolitics" within the European migration regime (Section 3). Subsequently, we show that the new volunteers' movement also comes with political possibilities through the creation of spaces of encounter (Section 4).

\section{From the Margin to the Mainstream: The Popularization of Refugee Solidarity and the Emergence of a New Dispositif of Helping}

In light of the rising number of asylum seekers arrivals over the course of 2015, concerned citizens jumped in where governmental actors failed to provide even the most basic necessities such as clothes, food, or accommodation (Speth \& Becker, 2016). To many of these new volunteers, the catchphrase "Refugees Welcome" became the popular mantra, which was even picked up by the traditionally conservative tabloid "Die Bild" (2017). Scholars and journalists alike have commented on this extraordinary development as a "summer of welcome" (Karakayali \& Kleist, 2016), an "explosion of citizens' commitment" (Hamann, Karakayali, Wallis, \& Höfler, 2016) or "mass mobilizations for refugees" (Deutsche Welle, 2016). Indeed, our own research has shown that even in rural areas, where asylum seekers were accommodated for the first time in a while, the number of people who were willing to volunteer often exceeded the actual number of refugees within the community; the phones of volunteer agencies at city administrations did not stop ringing, and volunteer initiatives were unable to cope with the sheer number of people willing to help. The readiness to donate was so strong that storehouses were piled up with goods waiting to be sorted and processed. This upsurge in citizens' commitment throughout Germany was not only a numerical increase but also brought new motivations, parameters, and practical forms of volun-

\footnotetext{
2 Despite our focus on pro-refugee mobilizations in this text, it is also crucial to highlight the "dark side of 'welcome culture'” (Jäckle \& König, 2016): an unprecedentedly high number of violent attacks on asylum seekers and their facilities, rapidly increasing popularity of the far-right party Alternative für Deutschland (AfD), and the most severe restrictions in German asylum law in two decades (Hess et al., 2017; Schwiertz \& Ratfisch, 2016).

${ }^{3}$ We put the term "apolitical" in inverted comas in order to highlight the emic use of this term. Analytically, however, we claim that it is impossible for refugee solidarity and help to remain apolitical, as we will demonstrate throughout this article.

${ }^{4}$ Following Michel Foucault (1978, p. 119 ff.), we understand the concept of the dispositif as a heterogeneous ensemble of utterances, actors, and rules, which follows particular philosophical, moral, and philanthropic propositions and, by doing so, legitimizes and "masks" specific practices. The concept is further exemplified in Section 2.

${ }^{5}$ Larissa Fleischmann has conducted intensive qualitative research on the topic of refugee solidarity in Germany. Through ethnographic fieldwork in various sites, she has participated in different events and meetings of volunteer initiatives and conducted more than thirty interviews with actors involved in the reception of asylum seekers. Elias Steinhilper investigates the processes of political self-organization of refugees. In this context he has conducted more than 30 in-depth interviews and participated in dozens of protest events and assemblies.
} 
teering, and was highly influenced by the image of the "refugee crisis".

\subsection{The Mobilizing Effects of the "Refugee Crisis"}

In parallel to the highly visible upsurge in citizens' commitment throughout Germany in 2015, the national and international media reported extensively on the increasingly tense situation at Europe's borders, accounting for and reproducing the notion of an unprecedented "refugee crisis" (see for example Holmes \& Castañeda, 2016; Kallius, Monterescu, \& Rajaram, 2016). On a daily basis, new reports on the "Balkan Route" contributed to the production of what De Genova (2013) has called a "border spectacle".

The image of the "crisis" seems to hold an important mobilizing effect. An explorative survey of the new volunteers by Karakayali and Kleist (2016) found that almost two-thirds of the respondents (66\%) were mobilised no earlier than summer 2015, when the media started to report extensively on the so-called "crisis". In addition, the authors assert that the media reports on refugees during summer 2015 formed an explicit and crucial motivating factor for the volunteers' engagement with refugees (see also Schwiertz \& Ratfisch, 2016). This was also confirmed by our empirical research. Many of the interviewed volunteers stated that they perceived a "practical urgency" to help in order to relieve "misery", spurred on mainly by media reports of the atrocities in the civil wars in Syria and Iraq or reports of sinking vessels in the Mediterranean.

Both tendencies, the overwhelming rise in citizens' commitment and the image of the "crisis", thus appear to be importantly connected and co-produced. The official German volunteering survey found that in 2009 less than $0.1 \%$ of German society was committed to refugees (Gensicke \& Geiss, 2010, p. 231). Recent surveys, however, point to an exponential increase in the number of committed citizens in support of refugees since 2011. Between 2011 and 2014, the number of volunteers rose by at least $70 \%$ (Karakayali \& Kleist, 2015). During the perceived "crisis", this trend accelerated, with the number of volunteers doubling in 2015 alone (Karakayali \& Kleist, 2016).

These findings resonate with previous contributions on the issue, in which scholars have indicated that the impetus for immediate action stems from the image of the "crisis". Fassin (2016) has argued that the "crisis" served to transmit the perception of an unprecedented humanitarian emergency situation or "moral crisis", demanding the immediate response of charitable citizens to those in need. Others have argued that the topic of (irregular) migration is particularly prone to alarmist perceptions of emergency and risk, as it is generally perceived as a deviation from a sedentary norm and a danger to sovereign power (see Malkki, 1996; Nyers, 2006a). In a similar vein, De Genova and Tazzioli (2016) emphasize how "crisis" narratives not only call for collective efforts by citizens but also legitimize technocratic emergency interventions by the state. Most importantly, the image of a "refugee crisis" tends not to regard the situation as an outcome of concrete political decisions and failures but instead puts forward a depoliticized and decontextualized view of asylum and migration more broadly (see for instance Calhoun, 2010). This is also mirrored in the volunteers' commitment to refugees, as we will demonstrate in the following section.

\subsection{Changing Motivations, Parameters and Practices of Support}

The image of the "crisis" not only mobilized an unprecedented number of citizens but also brought new motivations. Before the recent upsurge in refugee solidarity, committed citizens were a small minority in society and mainly originated in faith-based circles or networks of left-wing activists (see Twickel, 2016). However, for a large number of the new volunteers, neither religious nor political parameters played a major role (see Karakayali \& Kleist, 2016, or Mutz et al., 2015). The recent popularity of refugee solidarity has thus activated mainly "ordinary citizens" positioned in the socio-political "centre" of society. This is supported by various studies, showing that many of the newly engaged volunteers had previously been neither politically active nor dedicated to other areas of voluntary work (Daphi, 2016; Karakayali \& Kleist, 2016). At the same time, our own research finds that many of the new volunteers shy away from a clear political position and ascribe rather vague humanistic qualities to their actions. Many volunteers seem to frame their activities as a "sign of humanity", as one of our interlocutors termed it.

This indicates how a large number of the newly committed volunteers embed their activities in humanitarian logics, particularly those who started their activities during the "crisis" (Karakayali \& Kleist, 2016). Many understand their "help" as a humane duty to people in need, aimed at providing assistance and care in order to relieve human suffering (Mutz et al., 2015). This humanitarian framing is immanently connected to an "apolitical" selfunderstanding of the newly committed citizens. Our own findings suggest that many of the new volunteers claim that they do not "want to have anything to do with politics". By doing so, they constitute themselves as "neutral" individuals and establish a neat dividing line between their forms of helping, which are perceived as standing outside the realm of politics, and forms of "political activism". Many distance themselves from (leftist) activist groups which have been engaged in the field of refugee and migrant solidarity prior to the recent media attention on the topic. In contrast to the volunteers, such designated "activists" claim an explicit left to radical-left political standpoint for their actions, embedding their commitment in a wider context of structural criticisms of neoliberal, post-colonial, or capitalist structures. This also points to what was indicated by our empirical research: 
for many of the new volunteers, the "political" stood for the positioning on either one of the two sides, be it left or right, of the political spectrum.

Due to their prescribed "apoliticalness", however, the new volunteers fall short of embedding their activities in a wider political context. This also affects their ability to voice dissent, to take a stand, or to propose alternatives leading to formal political developments. At a first glance, they thus appear to be less "political"understood in a Rancièrian tradition as dissensus or "rupture" in the given order-than those who are committed to refugees and deliberately regard their activities as political action. However, in Section 4 we will outline how this preconception is confounded by unexpected effects and developments which point to the political qualities of the new volunteers' commitment.

These developments are in line with a general feature of humanitarian practice that has been widely discussed in anthropology and cultural studies (see for example Bornstein \& Redfield, 2011; Fassin, 2012; Feldman \& Ticktin, 2010; Ticktin, 2014): humanitarian actors depend on their dissociation from the field of the political, since politics and humanitarianism come to occupy opposing poles. Nyers (2006a, p. 32), for instance, has argued that "humanitarian action and political action are cast as two distinct and separate modes of acting and being-in-theworld". In contrast to the negative connotations that are ascribed to politics, humanitarianism is seen as its positive counterpart and becomes discursively connected to the principles of humanity, impartiality, and neutrality (Nyers, 2006a, p. 27).

\subsection{The Emergence of a New Dispositif of Helping}

The recent popularization of citizens' commitment to refugees, we argue, can be conceptualized as a shift towards a dispositif of helping, which builds on humanitarian parameters. It consists of an ensemble of sensemaking processes that evolve around the claim to provide ("apolitical") help to people in need and that are accompanied by an impetus to relieve human suffering. Foucault (1977, p. 194) understands the dispositif as:

a heterogeneous ensemble consisting of discourses, institutions, architectural forms, regulatory decisions, laws, administrative measures, scientific statements, philosophical, moral and philanthropic propositions.

Thus, we think of the dispositif surrounding refugee solidarity as the discursive sense-making processesincluding the motivations, principles, and framingsthat legitimize and guide concrete practices in support of refugees.

Such a conceptual take on the new trend of volunteering is useful for our overall argument for two reasons. First, it highlights the power relations that are immanent to such a dispositif of helping. According to Foucault (1977, p. 196), a dispositif is always inscribed into "a play of power", which conditions and is conditioned by certain types of knowledges. This indicates how different actors take part in and compete over the meanings and sensemaking processes in which the acts of volunteering for refugees become embedded. Indeed, Barnett (2017, p. 4) has recently identified this in the specific context of humanitarianism: "the world of care might present itself as an antidote to the world of power and interest, but it is not as innocent as it pretends to be". Second, and connectedly, the notion of the dispositif highlights the strategic functions of a dispositif of helping. Foucault has put this as follows: "its major function [is] at a given historical moment that of responding to an urgent need" ( $p$. 195 , emphasis in original). In the preceding paragraphs, we have sketched how the image of the "refugee crisis" appeared to demand immediate reactions and held important mobilizing effects. It consequently also points to the strategic function of the dispositif of helping in the governance of migration: it provided the necessary relief for governmental actors and thus presented a way out of the "crisis" which at the same time guaranteed the survival of the migration regime.

\section{Reinforcing an Exclusive Migration Regime: The New Dispositif of Helping as Antipolitics}

Journalists have celebrated and heralded the German Welcome Culture as an archetypical model of a transformative and progressive civil society (Dewast \& Chasturvedi, 2015; Freedland, 2015; Prantl, 2015). Scholars, however, have advocated a more cautious reading of the recent popularization of refugee solidarity (Scherr, 2016; Steinhilper \& Fleischmann, 2016; van Dyk, Dowling, \& Haubner, 2016). In a similar vein, we propose that an "apolitical" understanding of volunteering for refugees might lead to what Miriam Ticktin (2011) has termed the "antipolitics of care". Instead of contributing to a progressive change, the new volunteers might reinforce the established order by reproducing hegemonic discriminations and exclusions and thus contribute to the survival of a migration regime in crisis.

\subsection{The New Volunteers as Actors in a Restrictive Migration Regime}

Many studies of humanitarianism have questioned the conventional notion of humanitarian practice as a set of politically neutral and impartial practices (see Fassin, 2007; Feldman \& Ticktin, 2010). From this perspective, the "apolitical" claim needs to be unmasked as an illusion since the universal category of "humanity" is always embedded in a political context that is determined by sovereign power and the stratification of rights (see Scherr, 2016). Thus, authors such as Didier Fassin (2012) and Peter Nyers (2006a) have convincingly argued that, instead of constituting two separate areas, politics and humanitarian aid are inextricably connected. They point to the entangled nature of humanitarian and governmen- 
tal actors and speak of "the politics of humanitarianism" (Nyers, 2006a, p. 29) or forms of "humanitarian government" (Fassin, 2012). From this perspective, humanitarian practice becomes immanently complicit in the governance of migration. Ticktin (2011), for example, speaks of a "regime of care", which reduces refugees to their suffering and represents them as "bare life" that does not possess a "right to have rights". This might even lead to forms of "humanitarian violence", which occur when humanitarian actors and governmental actors work in perfect symmetry (Nyers, 2006a).

In his influential piece "The Anti-Politics Machine", Ferguson (1994) claims that the depoliticization of certain areas of policy leads to a decrease of their democratic scrutiny and makes governmental interventions appear to be "technical solutions to technical problems". Similarly, Nyers (2006a, p. 29) has argued that supposedly "apolitical" humanitarian interventions "work to establish the refugee phenomenon as a non-political occurrence". This tendency became explicit in the context of the recent upsurge in citizens' commitment to refugees and the shift towards a humanitarian dispositif of helping: the reception of asylum seekers is perceived as a solely humanitarian occurrence, detached from (globalized) political contexts.

In line with Fergusons' observations, the depoliticization of refugee solidarity has coincided with the strongest tightening of German asylum law since the early 1990s (Hamann et al., 2016; Pro Asyl, 2016). This includes the "asylum packages" II and III, the classification of further states as so-called "safe countries", as well as a tremendous increase in deportations (Bundesregierung, 2016; Gruppe Blauer Montag, 2017; Scherr, 2015a; Scherr \& Scherschel, 2015). These immediate and restrictive governmental responses are also encouraged by the image of the crisis, as different scholars have argued (see De Genova \& Tazzioli, 2016; Scherr, 2016). Despite deteriorating conditions for many asylum seekers in Germany, new volunteers have rarely engaged in public contestations of the recent governmental interventions (Omwenyeke, 2016; Ulu, Byakuleka, \& Arps, 2016). In our own empirical research projects, many of the volunteers interviewed stated that contestation of governmental politics lay outside their "sphere of responsibility" since it was considered incompatible with their neutral claim that they "merely" want to provide practical "help" to refugees. This, in many instances, coincided with a non-reflective acceptance and reproduction of government distinctions between those who are "wanted" and those who are "unwanted" and subsequently deported.

\subsection{Reproducing Exclusions and Conditioning Deportability}

Volunteering risks reproducing pre-existing notions of who counts as a "genuine" or a "bogus" refugee, based on the asylum seekers' nationality (see Schwiertz \& Ratfisch, 2016, p. 25). Larissa Fleischmann's research project has shown that many of the new volunteers have clear conceptions of who "deserves" their help: mainly Syrians or other nationalities with a good "Bleibeperspektive" ["perspective of staying"], especially families and women. In contrast, asylum seekers originating from African countries or single young man are often perceived as "undeserving". This notion is supported by a representative survey by the Robert Bosch Foundation (2014), which found that the readiness to help is significantly higher towards asylum seekers who are perceived to be refugees from war-torn countries and significantly lower towards "economic migrants", who are said to claim asylum on false pretences.

Different authors have illustrated how the emphasis on a humanitarian duty towards certain categories of migrants (i.e., those who are perceived as legitimately suffering) holds a strategic function: it serves to divert attention away from the increasingly repressive tendencies of the migration regime, that tends to illegalize a large number of migrants from the Global South. De Genova \& Tazzioli (2016, p. 27), for example, have argued that:

the spectacularization of the "humanitarian crisis" obscures other realities, most notably the subordinate incorporation of "rejected asylum-seekers" and other illegalized migrants through the exploitation of their labor.

The image of a "humanitarian crisis" thus legitimized the reception of some and the deportation of others.

\subsection{The Reproduction of Paternalism}

Our empirical research includes many instances in which volunteers have voiced clear preconceptions about the appropriate form of "helping" and determined its conditions and parameters. Some organized, amongst other activities, gardening, joint visits to museums, or sailing trips. Often, however, such activities were more in line with the benefactors' ideas and interests than with the concrete and immediate needs of newly arrived asylum seekers. Many academic studies have outlined how refugees are portrayed and de-subjectified as "mute victims" (Rajaram, 2002) or "speechless emissaries" (Malkki, 1996) through practices of humanitarian assistance. Instead of being recognized as selfdetermined individuals capable of desires, actions, and speech, or in other words, as political subjects with a "right to have rights" (Arendt, 1996), they are constituted as passive recipients of aid and charity (Nyers, 2006b). In consequence, humanitarian practice regularly constitutes asylum seekers as subjects who are reduced to their mere thankfulness and, in consequence, are increasingly dependent on the goodwill and intermediation of volunteers or other humanitarian actors (Hyndman, 2000; Khosravi, 2010). This image, which portrays asylum seekers as incapable of improving their situation on their own, reduces them to a state of passivity, infancy, and mute- 
ness (Fleischmann, 2015). According to Stierl (2016), this tendency has been importantly influenced by the more recent media attention towards forced migration, which has presented refugees as helpless victims of atrocious wars and ruthless people smugglers.

Interactions that are based on a perception of the refugees as helpless victims are present alongside asymmetric power relations and reproduce forms of paternalism and discrimination (see Barnett, 2017). Fassin (2012, p. 4) has outlined, how humanitarian assistance and compassion "always presupposes a relation of inequality" and an "attitude of superiority" of the benefactors. Instead of empowering refugees to speak for themselves, it is often the volunteers who speak for the refugees and define the conditions of the help that is offered (Jakob, 2015; Ulu et al., 2016). This image also risks silencing the struggles of forced migrants who have organized themselves for decades in order to become visible as political subjects and to fight for their rights (Klotz, 2016; Omwenyeke, 2016; Steinhilper, 2016). Activist groups, which were active in the field of refugee solidarity before the recent upsurge of citizens' commitment, have long broached the issue of paternalism and problematized internal power structures (see Transact, 2014). So far, however, a profound discussion along these lines has been limited with respect to the new citizens' initiatives.

In the preceding paragraphs, we have argued that the "apolitical" self-understanding of the volunteers presents a powerful fiction. Instead of being located outside politics, the new volunteers are entangled with governmental actors and reproduce and sustain hegemonic logics of the governance of migration in multiple ways. We thus suggest that the new forms of helping can figure as antipolitics and reinforce a repressive migration regime. And yet, the new dispositif of helping also comes with transformative political possibilities.

\section{Contesting Exclusive Migration Regimes: Spaces of Encounter and Interventions in Public Discourse}

The new popularization of volunteering and the shift towards a dispositif of helping also holds important transformative political qualities. Informed by Rancière (1999, 2010), we refer to the political as the possibility of altering, reforming, or contesting existing hegemonic structures towards a more egalitarian societal order. In the following sections, we will outline three such possibilities for political change within the new dispositif of helping. These are not purely theoretical in nature but are supported by the emerging body of empirical literature on the issue.

\subsection{Spaces of Encounter for Previously Detached Groups}

Even though many volunteers started their engagement with a humanitarian motive, claiming to be explicitly "apolitical", this framing is not necessarily static. Building on academic work that deals with the "transformative effects" of engagement in social movements and civil society more broadly (Della Porta, 2008; Goodwin, Jasper, \& Polletta, 2009), we propose that volunteering for refugees comes with a similar effect: those involved are shaped by interactions with others during their involvement. Reviewing the existing empirical evidence on the issue, we suggest that the diverse acts of volunteering create spaces of encounter between established residents and the newly arrived refugees that bring about important personal and interpersonal transformations through at least three mechanisms.

First, personal contact significantly reduces the propensity for "group-focused enmity" (Zick et al., 2008), including racism. In their analysis of determinants of violence against asylum seekers, König and Jäckle have found that:

these assaults are indeed more driven by a "fear of the unknown". The co-presence of foreigners, in contrast, fosters a social climate in which ethnic violence is less likely to occur. (2016, p. 22)

Personal engagement and continuous interaction with refugees is likely to have a lasting effect for those involved, as-in the words of Christian Jakob-they are an "antiserum against xenophobia" (Jakob, 2016). Accordingly, representative surveys have shown that those who are volunteering for refugees describe their experiences as predominantly positive (Ahrens, 2015) and are thus either developing or reinforcing tolerant attitudes towards refugees. This is of particular significance since, as empirical studies show, it is the first personal encounter with refugees for many of the new volunteers (Karakayali \& Kleist, 2016; Robert Bosch Stiftung, 2014).

Second, these encounters hold the potential for unveiling systemic contradictions within the European migration regime. In many cases of repeated exchange between volunteers and asylum seekers, affective relationships emerge that last even if the "welcomed refugee" is relabelled an "unwanted migrant" after the rejection of an asylum application. In a qualitative study, Hinger (2016) has traced this transformative process for volunteers in a welcome initiative in the German city of Osnabrück. Many members gradually became explicitly political through helping and have developed clear political positions (e.g., with regard to deportations). Individual cases necessarily unveil the connection between abstract (asylum) laws and the violent reality for those excluded from protection or social rights (Scherr, 2015a, 2015b). Similar processes of politicization within the dispositif of helping can be observed in many other groups in various cities (Fritsche, Kleine, \& Tietze, 2016), including the highly visible group Moabit hilft in Berlin (van Dyk et al., 2016).

\footnotetext{
6 "Group-focused enmity is a syndrome of various interrelated factors, all based on an ideology of inequality, devaluating out-groups based on race, sexual orientation, religion, or economic usefulness" (Zick et al., 2008).
} 
Third, the newly emerging initiatives are embedded in a social movement of volunteering for refugees which also includes experienced activists from anti-racist and immigrant-rights movements. Indeed, most of the newly emerging initiatives had to rely on the expertise of established actors in the field. In this regard, many of the regional Refugee Councils [Landesflüchtlingsräte] and the umbrella organization Pro Asyl have served as relays between new groups and the established immigrant rights movement, providing information, training, and contacts. A more direct space of encounter for diverse actors was formed by the network "Welcome2Stay", launched at a conference in summer 2016. It involves more than 800 members of welcome initiatives, anti-racist groups, and migrant self-organizations (Welcome2Stay, 2016)-from "ordinary citizens" to "radical-left activists". Another example of diffusion is provided by the anti-racist association glokal e.V., which has recently published a brochure "Willkommen ohne Paternalismus" ["Welcome without paternalism"] (2017), which builds on the explicit idea of assisting newly established welcome initiatives and of making accessible the "lessons learned" from earlier proimmigrant mobilizations. These networks often-though certainly not always-function as spaces of direct and indirect encounter for parts of society with previously little or no interaction (Fritsche et al., 2016). In consequence, debates with a long tradition in pro-immigrant and antiracist circles-on self-reflexivity in multicultural settings (critical whiteness as one variant), on the "limits" of help, or on the contextualization of forced migration (Transact, 2014)-have started to diffuse from an antiracist niche into broader areas of society.

\subsection{Breaking Isolation: The Dispositif of Helping as a Stepping-Stone to Empowerment}

The spaces of encounter also hold the potential to transform those with a history of forced migration and to support them in becoming political subjects beyond their ascribed role as passive recipients of government or civil society aid. For decades, organized refugees such as The Voice Refugee Forum, Women in Exile, or the Caravan for the Rights of Refugees and Migrants have criticised and resisted isolation from the majority population imposed by various means: accommodation in often peripheral areas (Pieper, 2008); until recently, mobility restrictions ["Residenzpflicht"], work bans, or food vouchers (Jakob, 2016). These measures amount to a system of "organized disintegration" (Täubig, 2009). The recently established welcome initiatives de facto contribute to breaking this isolation; no matter how banal or apolitical their activities might seem, they constitute at times unique access points to German society (see also Jungk, 2016), providing temporary relief from the often desolate life in the camps, as well as information and contacts. Various studies in other issue areas have shown that weak tiesrelatively loose relations to parts of society from which a certain actor would otherwise be isolated-are, in combination with affective and close strong ties, a necessary condition for processes of mobilizations in general (Diani \& McAdam, 2003; Granovetter, 1973) and for migrants in particular (Nicholls, 2008; Nicholls \& Uitermark, 2016). Through such channels, marginalized actors can tap material (information, money, logistics) and emotional resources (Han-Broich, 2015; Laubenthal, 2007) which are necessary for subsequent self-organization and empowerment. It remains subject to further specific empirical analysis to investigate if and how these latent resources embedded in newly emerging spaces of encounter (in large parts of Germany these were absent until the summer of migration) translate into processes of political subjectivation among refugees.

\subsection{Interventions in Public Discourse}

In many municipalities, members of newly established "welcome initiatives" interact regularly with neighbours, local administrations and politicians, welfare associations, and the media. This points to another political mechanism of volunteering for refugees: welcome initiatives foster understanding of the needs of refugees in neighbourhoods, intervene in public discourse and, by doing so, perform a crucial integrating role in society (see also Daphi, 2016; Speth \& Becker, 2016). Such processes can be traced in highly distinct contexts: a research project conducted in the wealthy neighbourhood of Hamburg-Harvestehude found that the work of welcome initiatives had contributed significantly to the mediation of residents' initial opposition to an accommodation centre and its transformation into strong approval (Friedrichs, Leßke, \& Schwarzenberg, 2017). Another non-representative study commissioned by the Robert Bosch Foundation which also included economically underprivileged neighbourhoods such as MarzahnHellersdorf and Neukölln-Britz mirrors these findings (Aumüller et al., 2015). In a similar vein, more than $90 \%$ of the respondents in the EFA II-study stated that, through volunteering, they aimed to publicly demonstrate that in Germany, "besides the far-right agitation and violence", there is "also a welcome culture" (Karakayali \& Kleist, 2016, authors' translation from German; see also Fritsche et al., 2016).

Both the unprecedented numerical strength and the diversity of the "movement of volunteering for refugees" (Karakayali \& Kleist, 2015, p. 19), combining internetsavvy young people with entrepreneurs, churches, retirees, and anti-racist structures, shaped public opinion. In this way, cooperation at the local level also combined with a strong pro-immigrant discourse at the national level. All of these political possibilities immanent in the new trend of volunteering underline our key argument: "apolitical" help presents a myth, even though many individuals involved perceive their activities in solely humanitarian terms. 


\section{Conclusion: Contextualizing Volunteering for Refugees}

Throughout this article we have unmasked forms of "apolitical" volunteering for refugees as a powerful myth. Far from being located outside politics, the new volunteers, who predominantly embed their activities in humanitarian parameters, have a political stake in the existent migration regime: they have guaranteed its survival amid a "crisis" of deficient migration and asylum policies.

We have offered a conceptual view of citizens' increasing commitment as a new dispositif of helping by scrutinizing how its humanitarian parameters come with ambivalent and, at times, contradictory effects. On the one hand, they reinforce and become complicit in an increasingly restrictive migration regime by reproducing dominant hierarchies, exclusions and discriminations. On the other hand, the new volunteers contest and transform the current migration regime. Whereas we have termed the former the antipolitics of volunteering, the latter constitutes, in a Rancièrian tradition, the essence of the political: the transformation of problematic societal structures in the direction of a more egalitarian order. We argue that this possibility for political transformation emerges when volunteers become aware of the powerful myth of "apolitical" help and begin to embed their volunteering activities in a wider context, instead of turning a blind eye to it. This involves the contextualization of volunteering for refugees in the spatial, social, institutional, and legal conditions of forced migration.

Last but not least, we want to highlight the empirical limits of this study. Our primary aim in this article was to combine and discuss existing studies in order to provide a more theoretically informed and systematic account of these recent developments. In this regard, we have introduced the idea of a new dispositif of helping. However, additional research is needed in various regards: firstly, our claims should be confronted with representative data on the motivations and framing of volunteers' engagement; secondly, qualitative and empirically rich research is needed to further refine our conceptualizations through an investigation of the power dynamics at play, the volunteers' sense-making processes, their daily practices, as well as their effects on the processes of emancipation among refugees.

After the more recent fading of the image of the "crisis" from the public eye, the question arises whether the recent mobilizations and popularizations of refugee solidarity will develop into sustainable and long-lasting commitment. This will depend to a great degree on the ability of the volunteers to think beyond the "crisis" and to re-politicize the topic of forced migration. Future humanitarian "crises", we argue, should be thought of as results of governmental decisions and contextual conditions. Furthermore, those who are affected by these processes must be empowered in order to obtain a political voice and to demand a "right to have rights". Under such circumstances, the Welcome Culture can bring about a lasting transformation towards a more egalitarian society with universal rights and global solidarity.

\section{Acknowledgements}

The authors thank the editors and four anonymous reviewers for their helpful comments and suggestions and are grateful for the financial support for this publication from the Open Access Fund as well as the Centre of Excellence "Social Foundations of Cultural Integration" of the University of Konstanz. Elias Steinhilper acknowledges the material and ideational support of the Institute of $\mathrm{Hu}$ manities and Social Sciences, Scuola Normale Superiore.

\section{Conflicts of Interests}

The authors declare no conflict of interests.

\section{References}

Ahrens, P.-A. (2015). Skepsis oder Zuversicht? Erwartungen der Bevölkerung zur Aufnahme von Flüchtlingen in Deutschland. (Sozialwissenschaftliches Institut der EKD, Ed.). Retrieved from https://www.ekd.de/si/ download/Fluechtlinge_21.12.15.pdf

Akrap, D. (2016, September 6). Germany's response to the refugee crisis is admirable. But I fear it cannot last. The Guardian. London. Retrieved from https:// www.theguardian.com/commentisfree/2015/sep/06/ germany-refugee-crisis-syrian

Arendt, H. (1996). We refugees. In M. Robinson (Ed.), Altogether elsewhere: Writers on exile (pp. 110-119). Fort Washington: Harvest Books.

Aumüller, S. J., Daphi, P., \& Biesenkamp, C. (2015). Die Aufnahme von Flüchtlingen in den Bundesländern und Kommunen. Behördliche Praxis und zivilgesellschaftliches Engagement. Stuttgart: Robert Bosch Stiftung.

Barnett, M. N. (2017). Paternalism beyond borders. Cambridge: Cambridge University Press.

Bornstein, E., \& Redfield, P. (2011). Forces of compassion: Humanitarianism between ethics and politics. Santa Fe: SAR Press.

Bundesregierung. (2016). Asylpaket II in Kraft. Kürzere Verfahren, weniger Familiennachzug. Retrieved from https://www.bundesregierung.de/Content/DE/Artik el/2016/02/2016-02-03-asylpaket2.html

Calhoun, C. (2010). The idea of emergency: Humanitarian action and global (dis)order. In D. Fassin \& M. Pandolfi (Eds.), Contemporary states of emergency: The politics of militar and humanitarian interventions ( $\mathrm{pp}$. 29-58). New York: Zone Books.

Daphi, P. (2016). Zivilgesellschaftliches Engagement für Flüchtlinge und lokale "Willkommenskultur". ApuZ 14-15/2016, 35-39.

De Genova, N. (2013). Spectacles of migrant "illegality": The scene of exclusion, the obscene of inclusion. Ethnic and Racial Studies, 36(7), 1180-1198. https:// doi.org/10.1080/01419870.2013.783710 
De Genova, N., \& Tazzioli, M. (2016). Europe/Crisis: New keywords of "the crisis" in and of "Europe". Zone Books.

Della Porta, D. (2008). Eventful protest, global conflicts. Distinktion: Scandinavian Journal of Social Theory, 9(2), 27-56.

Deutsche Welle. (2016, August 22). Eine Massenmobilisierung für Flüchtlinge. DW Online. Retrieved from http://www.dw.com/de/eine-massenmobilisierungfür-flüchtlinge/a-19470631

Dewast, L., \& Chasturvedi, A. (2015, September 8). Refugee crisis: Innovative ways Germans are welcoming them. Abc News.

Diani, M., \& McAdam, D. (Eds.). (2003). Social movements and networks: Relational approaches to collective action: Relational approaches to collective action. Oxford: Oxford University Press.

Die Bild. (2017, March 1). Die große Wir helfen Bild Aktion. Berlin. Retrieved from http://www.bild.de/ news/topics/fluechtlingshilfe/wir-helfen-buehne-423 85428.bild.html

Fassin, D. (2007). Humanitarianism as a politics of life. Public Culture, 19(3), 499-520.

Fassin, D. (2012). Humanitarian reason: A moral history of the present. Berkeley: University of California Press.

Fassin, D. (2016, April). From right to favor: The refugee crisis as moral question. The Nation.

Feldman, I., \& Ticktin, M. (2010). In the name of humanity. The government of threat and care. Durham: Duke University Press.

Ferguson, J. (1994). The anti-politics machine. Development, depoliticization, and bureaucratic power in Lesotho. Minneapolis: University of Minnesota Press.

Fleischmann, L. (2015). "We will rise": Die Stimmen der Geflüchteten in der aktuellen "Willkommenskultur" hören. Sicherheitspolitik-Blog.

Foucault, M. (1977). The confessions of the flesh. In C. Gordan (Ed.), Power/Knowledge: Selected interviews and other writings, 1972-1977 (pp. 1994-228). New York: Pantheon Books.

Foucault, M. (1978). Dispositive der Macht. Berlin: Merve Verlag.

Freedland, J. (2015, September 11). Mama Merkel has consigned the "ugly German" to history. The Guardian.

Friedrichs, J., Leßke, F., \& Schwarzenberg, V. (2017). Sie sozialräumliche Integration von Flüchtlingendas Beispiel des Flüchtlingsheims Sophienstr. in Hamburg-Harvesthude. Kurzbericht des Forschungsprojekts. Köln.

Fritsche, T., Kleine, C., \& Tietze, D. (2016). Helfen ist in der gegenwärtigen Situation ein politisches Statement. LuXemburg. Retrieved from http://www.zeit schrift-luxemburg.de/helfen-ist-in-der-gegenwaerti gen-situation-ein-politisches-statement

Geddes, A. (2017). How to reassure the "anxious middle"? Reflections on the drivers of migration and of migration politics. In F. Pastore (Ed.), Beyond the mi- gration and asylum crisis (pp. 103-107). Rome: Aspen Institute.

Gensicke, T., \& Geiss, S. (2010). Hauptbericht des Freiwilligensurveys 2009. München: Bundesministeriums für Familie, Senioren, Frauen und Jugend. Retrieved from https://www.bmfsfj.de/blob/93170/ 73111cb56e58a95dacc6fccf7f8c01dd/3-freiwilligen survey-hauptbericht-data.pdf

glokal e.V. (2017). Willkommen ohne Paternalismus. Berlin: glokal e.V.

Glorius, B. (2017). "Wir schaffen das": A German perspective on refugees and bottom-up integration. In F. Pastore (Ed.), Beyond the migration and asylum crisis. Options and lessons for Europe. Rome: Aspen Institute.

Goodwin, J., Jasper, J. M., \& Polletta, F. (Eds.), (2009). Passionate politics: Emotions and social movements. Chicago: University of Chicago Press.

Granovetter, M. S. (1973). The strength of weak ties. American Journal of Sociology, 78(6), 1360-1380.

Gruppe Blauer Montag. (2017). "Flüchtlingskrise" und autoritäre Integration. Zu einigen Aspekten der Reorganisation staatlicher Kontrollpolitiken. Sozial.Geschichte Online, 20. Retrieved from https:// sozialgeschichteonline.files.wordpress.com/2016/12 /blauer-montag_flc3bcchtlingskrise_sgo-20-2017.pdf

Hamann, U., \& Karakayali, S. (2017). Practicing Willkommenskultur: Migration and solidarity in Germany. Intersections, 2(4), 69-86.

Hamann, U., Karakayali, S., Wallis, M., \& Höfler, L. J. (2016). Koordinationsmodelle und Herausforderungen ehrenamtlicher Flüchtlingshilfe in den Kommunen. Berlin: Bertelsmann Stiftung.

Han-Broich, M. (2015). Engagement in der Flüchtlingshilfe-Eine Erfolg versprechende Integrationshilfe. ApuZ 14-15/2015. Retrieved from http:// www.bpb.de/apuz/203551/engagement-in-der-flue chtlingshilfe? $\mathrm{p}=$ all

Hess, S., Kasparek, B., Kron, S., Rodatz, M., Schwertl, M., \& Sontowski, S. (2017). Der lange Sommer der Migration. Grenzregime III. Berlin: Assoziation A.

Hinger, S. (2016). Asylum in Germany: The making of the "crisis" and the role of civil society. Human Geography, 9(2), 78-88.

Holmes, S. M., \& Castañeda, H. (2016). Representing the "European refugee crisis" in Germany and beyond: Deservingness and difference, life and death. American Ethnologist, 43(1), 12-24.

Hyndman, J. (2000). Managing displacement. Refugees and the politics of humanitarianism. Minneapolis: University of Minnesota Press.

Jäckle, S., \& König, P. D. (2016). The dark side of the German "welcome culture": Investigating the causes behind attacks on refugees in 2015. West European Politics, 2382(August), 1-29.

Jakob, C. (2015, August 14). Ein Sofa ist gut, Respekt ist besser. Die Tageszeitung. Berlin. Retrieved from http://www.taz.de/!5220027 
Jakob, C. (2016). Die Bleibenden. Wie Flüchtlinge Deutschland seit 20 Jahren verändern. Berlin: Ch. Links Verlag.

Jungk, S. (2016). Willkommenskultur. Von neuen Chancen, alten Fehlern und Versäumnissen. Ein Essay. Widerprüche, 141, 99-110.

Kallius, A., Monterescu, D., \& Rajaram, P. K. (2016). Immobilizing mobility: Border ethnography, illiberal democracy, and the politics of the "refugee crisis" in Hungary. American Ethnologist, 43(1), 25-37.

Karakayali, S., \& Kleist, O. (2015). EFA-Studie. Strukturen und Motive der ehrenamtlichen Flüchtlingsarbeit (EFA) in Deutschland. Berlin: Berliner Institut für empirische Integrations- und Migrationsforschung.

Karakayali, S., \& Kleist, O. (2016). EFA-Studie II. Strukturen und Motive der Ehrenamtlichen Flüchtlingsarbeit (EFA) in Deutschland. Berlin: Berliner Institut für empirische Integrations- und Migrationsforschung.

Kasparek, B., \& Speer, M. (2015). Of hope. Ungarn und der lange Sommer der Migration. Retrieved from bordermonitoring.eu/ungarn/2015/09/of-hope

Khosravi, S. (2010). "Illegal" traveller: An autoethnography of borders. Basingstoke: Palgrave Macmillan.

Klotz, S. (2016). Selbstorganisation von AsylsuchendenTeilhabeforderungen durch Zuwanderung. Forschungsjournal Soziale Bewegungen, 2, 60-69.

Kreck, L., \& Gerbing, S. (2015). Solidarität statt Hilfe. Interview mit Refugees Welcome Karoviertel und Patrick, einem Besetzer des Oranienplatzes. Prager Frühling.

Laubenthal, B. (2007). Der Kampf um Legalisierung: Soziale Bewegungen illegaler Migranten in Frankreich, Spanien und der Schweiz. Frankfurt: Campus.

Malkki, L. (1996). Speechless emissaries: Refugees, humanitarianism, and dehistoricization. Cultural Anthropology, 11(3), 377-404. https://doi.org/ 10.1525/can.1996.11.3.02a00050

Mutz, G., Costa-Schott, R., Hammer, I., Layritz, G., Lexhaller, C., Mayer, M., . . . Wolff, L. (2015). Engagement für Flüchtlinge in München. München: Hochschule München.

Nicholls, W. (2008). The urban question revisited: The importance of cities for social movements. International Journal of Urban and Regional Research, 32(4), 841-859.

Nicholls, W., \& Uitermark, J. (2016). Cities and the immigrant rights movement. A comparison of activism in the US, France, and the Netherlands. Hoboken: WileyBlackwell.

Nyers, P. (2006a). Rethinking refugees. Beyond states of emergency. London: Routledge.

Nyers, P. (2006b). Taking rights, mediating wrongs: Disagreements over the political agency of non-status migrants. In The politics of protection. Sites of insecurity and political agency (pp. 48-67). Basingstoke: Sage.

Omwenyeke, S. (2016). Solidarität statt Paternalismus.
Migration-Online.de. Retrieved from http://www. migration-online.de/beitrag._aWQ9MTAxNTU_.html

Paterson, T. (2015, September 7). Refugee crisis: Munich's citizens welcome refugees with open arms. The Independent.

Pieper, T. (2008). Die Gegenwart der Lager. Zur Mikrophysik der Herrschaft in der deutschen Flüchtlingspolitik. Münster: Westfälisches Dampfboot.

Prantl, H. (2015, September 7). Viewpoint: Munich migrant welcome shames Europe. BBC News.

Pro Asyl. (2016). Asylpaket II in Kraft: Überblick über die geltenden asylrechtlichen Änderungen.

Rajaram, P. K. (2002). Humanitarianism and representations of the refugee. Journal of Refugee Studies, 15(3), 247-264.

Rancière, J. (1999). Disagreement: Politics and philosophy. Minneapolis: University of Minnesota Press.

Rancière, J. (2010). Dissensus: On politics and aesthetics. London: Continuum Publishing Group.

Robert Bosch Stiftung. (2014). Asyl und Asylbewerber: Wahrnehmungen und Haltungen der Bevölkerung 2014. Stuttgart: Robert Bosch Stiftung.

Scherr, A. (2015a). Abschiebungen. Kursbuch, 183, 60-75.

Scherr, A. (2015b). Wer soll deportiert werden? Wie die folgenreiche Unterscheidung zwischen den "wirklichen" Flüchtlingen, den zu Duldenden und den Abzuschiebenden hergestellt wird. Soziale Probleme.

Scherr, A. (2016). Sozialstaat, Soziale Arbeit und die Grenzen der Hilfe. Neue Praxis.

Scherr, A., \& Scherschel, K. (2015). Einleitung: Flucht und Deportation-Was ist das soziale Problem? Soziale Probleme, 26(2), 119-122. https://doi.org/ 10.1007/s41059-015-0008-6

Schwiertz, H., \& Ratfisch, P. (2016). Antimigrantische Politik und der 'sommer der Migration." Retrieved from http://www.rosalux.de/publication/42062

Speth, R., \& Becker, E. (2016). Zivilgesellschaftliche Akteure und die Betreuung geflüchteter Menschen in deutschen Kommunen. Berlin: Maecenata Institut \& Deutsches Institut für Urbanistik.

Steinhilper, E. (2016). Selbstbewusst und laut. Politischer Protest von Geflüchteten. BpB Kursdossier "Zivilgesellschaftliches Engagement in Der Migrationsgesellschaft." Retrieved from http://www.bpb.de/ge sellschaft/migration/kurzdossiers/227542/politische -proteste-von-gefluechteten?p=all

Steinhilper, E., \& Fleischmann, L. (2016). Die Ambivalenzen eines neuen Dispositivs der Hilfe: Zur Rolle der Zivilgesellschaft seit dem langen Sommer der Migration. Neue Praxis, Special Issue 13, 60-72.

Stierl, M. (2016). Maritime humanitarians, migrant suffering and the idea of Europe. Antipode.

Täubig, V. (2009). Totale Institution Asyl Empirische Befunde zu alltäglichen Lebensführungen in der organisierten Desintegration. Weinheim: Juventa.

The Economist. (2015, September). "Germany! Germany!" Ordinary Germans, not their politicians, have taken the lead in welcoming Syria's refugees. The 
Economist. Retrieved from http://www.economist. com/news/briefing/21664216-ordinary-germans-not -their-politicians-have-taken-lead-welcoming-syrias

Ticktin, M. (2011). Casualties of care. Immigration and politics of humanitarianism in France. Berkeley: University of California Press.

Ticktin, M. (2014). Transnational humanitarianism. Annual Review of Anthropology, 43, 273-89.

Transact. (2014). How is your liberation bound up with mine? Berlin. Retrieved from https://transact. noblogs.org/files/2014/02/transact6_en.pdf

Twickel, C. (2016). Refugees Welcome: Vom Slogan zum Sommermärchen. Heimatkunde. Migrationspolitisches Portal. Retrieved from https://heimatkunde. boell.de/2016/03/03/refugees-welcome-vom-slogan -zum-sommermaerchen
Ulu, T., Byakuleka, B. B., \& Arps, J. O. (2016). “Nur Essen austeilen alleine reicht nicht"-Turgay Ulu und Bino Byansi Byakuleka im Gespräch. In Heimatkunde. Berlin: Heinrich-Böll-Stiftung.

van Dyk, S., Dowling, E., \& Haubner, T. (2016). Für ein rebellisches Engagement. Blätter Für Deutsche Und Internationale Politik, 2/2016.

Welcome2Stay. (2016). Pressemitteilung 13 Juni 2016. Retrieved from http://welcome2stay.org/de/ startseite

Zick, A., Wolf, C., Küpper, B., Davidov, E., Schmidt, P., \& Heitmeyer, W. (2008). The syndrome of groupfocused enmity: The interrelation of prejudices tested with multiple cross-sectional and panel data. Journal of Social Issues, 64(2), 363-383.

\section{About the Authors}
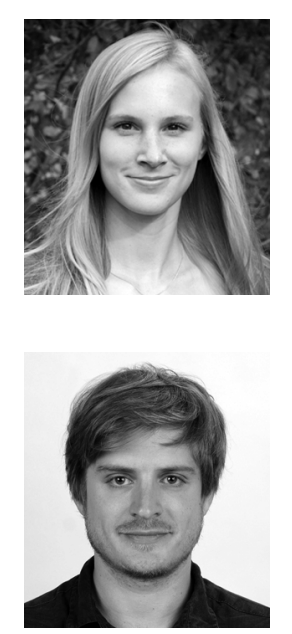

Larissa Fleischmann has been a member of the department of Social and Cultural Anthropology at the University of Konstanz since 2014. She also forms part of the interdisciplinary graduate college "Europe in the Globalized World" at the Centre of Excellence "Cultural Foundations of Social Integration" at the same university. In her recent research project, she investigates the manifold acts in support of refugees as well as the forms of solidarity that developed in Germany around the so-called "refugee crisis" of late summer 2015.

Elias Steinhilper is a political sociologist with a particular interest in migration studies, social movements, and human rights. He is currently working on a PhD project under the supervision of Donatella della Porta at Scuola Normale Superiore in Florence on political protest for rights and recognition of forced migrants in Germany and France. He has held visiting researcher positions at HU Berlin, UC Berkeley, and Sciences Po Paris. 